\title{
Biological and physico-chemical processes influence cutin and suberin biomarker distribution in two Mediterranean forest soil profiles
}

\author{
Anna Andreetta $\cdot$ Marie-France Dignac • \\ Stefano Carnicelli
}

Received: 16 February 2011/ Accepted: 14 December 2011

(C) Springer Science+Business Media B.V. 2011

\begin{abstract}
Recent investigations have shown macromolecules, such as cutins, and suberins as effective markers for above and belowground plant tissues. These biopolyesters contain structural units specific for different litter components and for root biomass. The aim of this work was to understand the fate of plant organic matter $(\mathrm{OM})$ in Mediterranean forest soils by evaluating the incorporation of cutin and suberin by measuring specific biomarkers. Soil and plant tissue (leaves, woods and roots) samples were collected in two mixed Mediterranean forests of Quercus ilex (holm oak) in costal stands in Tuscany (central Italy), which have different ecological and edaphic features. Ester-bound lipids of mineral and organic horizons and the overlying vegetation were analysed using the saponification method in order to depolymerise cutins and suberins and release their specific structural units. Cutin and suberin specific aliphatic monomers were identified and quantified by gas chromatographic techniques. The distribution of cutin and suberin specific monomers in plant tissue
\end{abstract}

A. Andreetta $(\bowtie) \cdot$ S. Carnicelli

Di.P.S.A. Scienze delle Produzioni Vegetali, del Suolo e dell'Ambiente Agroforestale, Piazzale delle Cascine,

18, 50144 Firenze, Italy

e-mail: anna.andreetta@unifi.it

M.-F. Dignac

INRA, Laboratory of Biogeochemistry and Ecology of Continental Ecosystems, UMR Bioemco, CNRS, UPMC, 78850 Thiverval-Grignon, France suggested that mid-chain hydroxy acids can be used as leaf-specific markers and $\alpha, \omega$-alkanedioic acids and $\omega \mathrm{C}_{18: 1}$ as root-specific markers. Differences in the distributions of biomarkers specific for above and belowground plant-derived $\mathrm{OM}$ was observed in the two types of soils, suggesting contrasted degradation, stabilisation and transport mechanisms that may be related to soil physico-chemical properties. The acidic and dry soil appeared to inhibit microbial activity, favouring stabilization of leaf-derived compounds, while, in the more fertile soil, protection within aggregates appeared to better preserve root-derived compounds.

Keywords Cutins $\cdot$ Suberins $\cdot$ Mediterranean . Forest soils $\cdot$ Soil organic matter

\section{Introduction}

Plant molecular structures are considered to be a driver of C stabilisation in soil (Marschner et al. 2008; Nierop 1998; Kögel-Knabner 2002). Therefore, tracing plant tissues in soil organic matter (SOM) can improve the understanding of SOM accumulation mechanisms (Crow et al. 2009). Aliphatic compounds often accumulate in soils, thus contributing to SOM stabilisation (Nierop 1998; Almendros et al. 2000), and may be preserved preferentially with respect to other compounds, such as lignin, in both forest 
(Rumpel et al. 2004) and cultivated (Dignac and Rumpel 2006) soils. A better knowledge of these dynamics might improve soil management strategies and practices to increase the SOC pool (Lorenz et al. 2007). Molecular characterisation of lipids in soil and the overlying vegetation has shown that lipid markers in soils remain intact when compared with the corresponding plant tissues, suggesting that plantderived lipids are valuable biogeochemical indicators of the SOM sources (Bull et al. 2000; Otto and Simpson 2005). Furthermore, they are also proposed as effective bioindicators for investigation on SOM accumulation (Crow et al. 2009) and degradation processes (Otto and Simpson 2006) as well as for pastvegetation reconstruction (Jansen and Nierop 2009). Within the main sources of plant-derived aliphatic compounds (Nierop 1998; Augris et al. 1998) recent studies have addressed macromolecules such as cutin and suberin as effective markers for above and belowground plant tissues (Mendez-Millan et al. 2010a, 2011). Cutin and suberin are bio-macromolecules common in vascular plants, primarily functioning as barriers to prevent water loss. Cutin is a major component of leaf cuticle and is present on every aerial organ of plant, forming a barrier between these parts and their environment (Hunneman and Eglinton 1972; Riederer et al. 1993). Cutin is a biopolyester, mainly composed of short chain $\left(\mathrm{C}_{14}-\mathrm{C}_{18}\right)$ hydroxyand epoxy fatty acids (Holloway and Brown 1981). Suberin, a polymer containing aromatics and polyesters, predominantly of long chain $\left(\mathrm{C}_{20}-\mathrm{C}_{32}\right)$ aliphatic acids, diacids and $\omega$-hydroxy acids (Bernards 2002), occurs in the periderm of roots and bark, functioning as a barrier for underground parts, wound surfaces and a variety of internal organs (Kolattukudy 1980). Beside their potential variability in relation to water stress, cutin and suberin might also be used to assess the contribution of root-derived C to SOM (Crow et al. 2009; Mendez-Millan et al. 2010a). Root-derived SOM plays a major role for $\mathrm{C}$ cycling and $\mathrm{C}$ storage in soils, as a considerable proportion becomes incorporated into the soil as below-ground input (KögelKnabner 2002; Rasse et al. 2005). Although the interest in the dynamics of root-derived lipids in soil is increasing (Wiesenberg et al. 2010; Otto and Simpson 2006; Jansen et al. 2006), the understanding of rootderived C contribution to soil lipids is still unclear (Feng and Simpson 2007), even if such knowledge might help understanding the specific contributions of root and shoot derived $\mathrm{OM}$ to the storage of organic carbon in soils.

This study aimed to address the contribution of root-derived $\mathrm{C}$ to $\mathrm{SOC}$ and the mechanisms driving this contribution in two Mediterranean forests of Italy. Plant tissue structure of Mediterranean sclerophyllous shrubs and trees is strictly related to the strategies they enact to cope with water stress conditions (Bussotti et al. 2003). Thus, the choice of these biomarkers may be particularly indicated for the Mediterranean environment and might highlight changes according to water stress. In order to evaluate root/shoot contribution to SOM, the following specific objectives were addressed:

a. identification of specific biomarkers of aboveground litter (leaves, woody debris) and of root biomass, through quantification of aliphatic monomers specific for cutins and suberins in the plant inputs to soil;

b. evaluation of the contribution of specific biomarkers for litter and root biomass, in two different forest humus forms (mesomull and amphimus) and the corresponding soils (Haplic Arenosol and Haplic Phaeozem).

\section{Materials and methods}

Study sites and sampling

The selected study sites, Cala Violina (CV) and Colognole (CL), were located on two Holm oak, Quercus ilex L., Mediterranean forests, in the same region (on the coast of Tuscany, Italy) but with contrasting ecological features. The forest vegetation consists of adult (40-60 years) Holm oak stands mixed with different broadleaved species at both sites. Climatic data for both areas were reported by Bussotti et al. (2000). The mean yearly precipitations were $978 \mathrm{~mm}$ at CL and $637 \mathrm{~mm}$ at CV (20 years historical series 1955-1974, Bigi and Rustici 1984). The mean annual temperatures were $15.1^{\circ} \mathrm{C}$ at $\mathrm{CL}$ and $15.5^{\circ} \mathrm{C}$ at $\mathrm{CV}$. The $\mathrm{CV}$ stand grows in quite xeric conditions, with 5 months of water deficit in the soil (Bigi and Rustici 1984). On the other hand, CL, thanks to both rainfall and higher soil available water capacity (AWC), is characterised by a better water supply, with no water stress for the vegetation. 
Soils were classified as Haplic Arenosol (Dystric) in $\mathrm{CV}$ and as Haplic Phaeozem (Episkeletic) in CL (FAO 2006). The main physical and chemical properties of the soils are summarised in Tables 1 and 2. Humus form in CV was classified as a mesomull (Jabiol et al. 2007) with a weak-structured first mineral horizon, while in CL an amphimus was found. Amphimus is associated with highly seasonal mull-forming activity (Galvan et al. 2008; Tagger et al. 2008) and it is characterised by features of mull, as a crumbystructured mineral A-horizon, and moders, as the presence of the overlying organic $\mathrm{OH}$ horizon. Both types of humus are expression of specific pedofauna strategies to cope with Mediterranean climate constrains as summer drought and seasonal fluctuations.

Both soils were sampled and described in June 2009. Triplicates of each soil horizon were taken in three different points and then analysed separately. Organic horizons were sampled by $25 \times 25 \mathrm{~cm}$ sampling frame. The $\mathrm{AE}, \mathrm{E}, \mathrm{BE}$ horizons in $\mathrm{CV}$ and $\mathrm{OF}, \mathrm{OH}$, $\mathrm{Ah}, \mathrm{AB}$ and $\mathrm{Bw}$ horizons in $\mathrm{CL}$, were used for this study. Samples of litter and roots were composited from samples taken from different random positions and in two different sampling seasons (June 2009 and September 2009) to compensate for spatial and temporal variability of plant tissues. Litter was separated in its major components: Quercus ilex leaves, acorns, woods, flowers and leaves from other plant species. The Quercus ilex leaves, the dominant component of the litter, and the woody debris were considered for the analysis. Roots were collected during sampling and after sieving of soil material $(2 \mathrm{~mm})$. For each composite sample three sub-samples of plant tissues were made for the analyses.

\section{Analysis of the biomarkers: cutins and suberins}

Free lipids extraction

Soil samples were freed from roots by handpicking, air-dried and successively sieved at $200 \mu \mathrm{m}$. Plant tissues ( $Q$. ilex leaves, roots and wood) after air-dried, were sieved at $100 \mu \mathrm{m}$.

In order to remove free lipids, samples of soils $(5 \mathrm{~g})$, plant tissues and organic horizons $(2 \mathrm{~g})$ were extracted successively (three times) using as extraction solvent dichloromethane/methanol 2:1 (V:V). For two times, the samples were ultrasonicated for $20 \mathrm{~min}$ with $10 \mathrm{ml}$ of extraction solvent, shaken for $2 \mathrm{~h}$ and subsequently centrifuged for $10 \mathrm{~min}$ at 2,200 rpm. After the extraction of supernatant, the soil residues were centrifuged with $5 \mathrm{ml}$ of extraction solvent. The residues were then air-dried and used for cutin and suberin depolymerization (Mendez-Millan et al. 2010a, b, 2011).

\section{Cutin-suberin characterization}

A saponification method was adopted to release specific monomers of cutin and suberin from both plant and soil samples, since it was considered a more sensitive method than THM (thermally assisted hydrolysis and methylation) to obtain ester-linked compounds from soils (Naafs and van Bergen 2002), and was shown to release appropriate amounts and diversity of monomers (Mendez-Millan et al. 2010b) when compared to $\mathrm{CuO}$ oxidation and transesterification methods.

Table 1 Soil and plant tissues properties of Cala Violina (CV)

\begin{tabular}{|c|c|c|c|c|c|c|c|c|}
\hline Horizons & Depth $(\mathrm{cm})$ & $\mathrm{C}\left(\mathrm{mg} \mathrm{g}^{-1}\right)$ & $\mathrm{N}\left(\mathrm{mg} \mathrm{g}^{-1}\right)$ & $\mathrm{C} / \mathrm{N}$ & $\mathrm{pH}$ & $\mathrm{BD}\left(\mathrm{g} \mathrm{cm}^{-3}\right)$ & Sand $(\%)$ & Clay $(\%)$ \\
\hline $\mathrm{AE}$ & $0-5$ & 104.7 & 6.3 & 16.7 & 6.1 & 0.98 & 81.5 & 5.8 \\
\hline $\mathrm{E}$ & $5-11$ & 9.3 & 0.6 & 15.7 & 4.8 & 1.23 & 89.1 & 3.8 \\
\hline $\mathrm{BE}$ & $11-30$ & 14.2 & 0.6 & 22.6 & 4.4 & 1.25 & 81.2 & 5.5 \\
\hline Bw & $30-55$ & 6.1 & 0.3 & 20.6 & 4.6 & 1.28 & 82.8 & 5.8 \\
\hline $\mathrm{BC}$ & $55-75$ & 2.1 & 0.2 & 12.5 & 5.8 & & 88.1 & 3.3 \\
\hline $\mathrm{C}$ & $75-120+$ & 1.4 & 0.1 & 11.0 & 6.5 & & 92.2 & 2.8 \\
\hline \multicolumn{9}{|c|}{ Plant tissues } \\
\hline Leaves & & 495.6 & 12.2 & 40.7 & & & & \\
\hline Roots & & 362.8 & 7.0 & 51.8 & & & & \\
\hline Woods & & 414.6 & 8.8 & 47.1 & & & & \\
\hline
\end{tabular}


Table 2 Soil and plant tissues properties of Colognole (CL)

\begin{tabular}{llllllll}
\hline Horizons & Depth $(\mathrm{cm})$ & $\mathrm{C}\left(\mathrm{mg} \mathrm{g}^{-1}\right)$ & $\mathrm{N}\left(\mathrm{mg} \mathrm{g}^{-1}\right)$ & $\mathrm{C} / \mathrm{N}$ & $\mathrm{pH}$ & Sand $(\%)$ & Clay $(\%)$ \\
\hline $\mathrm{OF}$ & $-3-(-2)$ & 361.2 & 17.8 & 20.3 & & & \\
$\mathrm{OH}$ & $-2-0$ & 329.1 & 17.2 & 19.2 & & & \\
$\mathrm{~A}$ & $0-5$ & 75.5 & 4.7 & 16.2 & 7.3 & 58.5 & 20.5 \\
$\mathrm{AB}$ & $5-15$ & 32.0 & 2.3 & 14.0 & 7.5 & 63.2 & 19.5 \\
$\mathrm{Bw}$ & $15-35$ & 12.6 & 1.0 & 13.2 & 7.5 & 59.5 & 23.8 \\
2Bw & $35-40$ & & & & 7.0 & 38.9 & 35.3 \\
Plant tissues & & 434.5 & 13.2 & 32.9 & & & \\
Leaves & & 360.1 & 8.0 & 45.0 & & & \\
Roots & & 416.8 & 13.6 & 30.6 & & & \\
Wood & & & & & &
\end{tabular}

The depolymerisation method is described in detail in Mendez-Millan et al. (2010b). Lipid-free samples (100 $\mathrm{mg}$ for plants and organic horizons and $1 \mathrm{~g}$ for soils) were refluxed for $18 \mathrm{~h}$ in an aqueous solution of potassium hydroxide in $\mathrm{MeOH}(6 \% \mathrm{KOH} / \mathrm{MeOH})$. The solution was filtered and the residue washed with $\mathrm{MeOH} /$ water. After conversion in their acidic form using $\mathrm{HCl}$, released biomarkers were extracted with DCM.

Depolymerisation extracts were dissolved in pyridine. Silylation with BSTFA ( $N, O$-bis(trimethylsilyl)trifluoroacetamide) containing $1 \%$ of trimethylchlorosilane (TMCS) was performed in order to transform hydroxy and carboxylic acid functions in their trimethylsilyl ether and ester derivatives (TMS ether/TMS ester).

Silylated saponification products were separated with a HP 6890 gas chromatograph (GC) equipped with a SGE BPX-5 column (50 m long, diameter $0.25 \mathrm{~mm}$, coating $0.32 \mu \mathrm{m}$ ). The $\mathrm{GC}$ oven temperature was programmed at $100^{\circ} \mathrm{C}$ for $2 \mathrm{~min}$, then from 100 to $150^{\circ} \mathrm{C}$ at $10^{\circ} \mathrm{C} / \mathrm{min}$, from 150 to $200^{\circ} \mathrm{C}$ at $5^{\circ} \mathrm{C} /$ min, and finally at a rate of $2^{\circ} \mathrm{C} / \mathrm{min}$ from 200 to $350^{\circ} \mathrm{C}$ and $5 \mathrm{~min}$ at $350^{\circ} \mathrm{C}$. The compounds of interest were chromatographically well resolved for plant tissues and soil samples in both sites.

Compounds were identified with an Agilent HP5973 Electron Impact (70 eV, scan range $m / z$ 40-700) mass spectrometer (MS), coupled to the GC, according to their fragmentation ions supported by comparison with published mass spectra (Eglinton et al. 1968; Hunneman and Eglinton 1972; Holloway and Deas 1973; Mendez-Millan et al. 2011) and with mass spectra library (Wiley). The aliphatic monomers were then quantified by GC/flame ionisation detection (FID) by using nonadecanoic acid standard, which was added prior to derivatisation.

\section{Results}

Content and distribution of aliphatic monomers in plant tissues and soil samples

Alcohols and carboxylic acids are derived from vascular plants (Kolattukudy 1980) but may be also produced by microorganisms (Harwood and Russell 1984). To avoid misinterpretation, $n$-carboxylic acids and alcohols were not considered as appropriate plant tissue markers since they are not source specific and consequently they are not discussed in this study.

$\omega$-hydroxy carboxylic acids

Major compounds in the saponified extracts of roots (Table 3) were $\omega$-hydroxy carboxylic acids (from $\mathrm{C}_{16}$ to $\mathrm{C}_{26}$ ) with 39.6 and $35.0 \%$. By contrast, the relative abundance of this class of compounds in leaf tissues was low, 4.0 and 5.4\%, respectively in CV and CL. 18-Hydroxy octadecenoic acid was the dominant monomer identified in root tissues, representing $27.7 \%$ of total monomers in CV and $23.6 \%$ in CL, in agreement with a pattern previously found for Quercus robur roots (Nierop et al. 2003). By contrast, this compound was not identified at all in leaves. Long chain $\omega$-hydroxy acids with more than $20 \mathrm{C}$ were 
observed in all tissues, except for $\omega \mathrm{C}_{26}$ that was not released from woody parts.

The contribution of $\omega$-hydroxy acids observed in soils (Table 4) differed markedly between the two sites. In CV their concentration increased in the deeper horizons from 4,284 $\mu \mathrm{g} \mathrm{g}^{-1} \mathrm{OC}$ in AE to 8,269 $\mu \mathrm{g} \mathrm{g}^{-1}$ $\mathrm{OC}$ in $\mathrm{BE}$ with a relative abundance, respectively, of 20.4 and $29.3 \%$. All the compounds from $\omega \mathrm{C}_{16}$ to $\omega \mathrm{C}_{26}$ were identified in the mineral horizons; however, their relative abundance changed along the profile. $\omega \mathrm{C}_{18: 1}$ was the dominant compound in $\mathrm{AE}\left(1,720 \mu \mathrm{g} \mathrm{g}^{-1} \mathrm{OC}\right)$ and in $\mathrm{E}\left(3,085 \mu \mathrm{g} \mathrm{g}^{-1} \mathrm{OC}\right)$, while $\omega \mathrm{C}_{22}\left(2,819 \mu \mathrm{g} \mathrm{g}^{-1}\right.$ OC) and $\omega \mathrm{C}_{24}\left(1,533 \mu \mathrm{g} \mathrm{g}^{-1} \mathrm{OC}\right)$ dominated in $\mathrm{BE}$ horizon. The total contribution of long chain compounds, predominating in suberins, increased along the profile with a concentration of $1,651 \mu \mathrm{g} \mathrm{g}^{-1} \mathrm{OC}$ in $\mathrm{AE}$, $3,269 \mu \mathrm{g} \mathrm{g}^{-1} \mathrm{OC}$ in $\mathrm{E}$ and $5,707 \mu \mathrm{g} \mathrm{g}^{-1} \mathrm{OC}$ in BE. The opposite trend was observed in CL site, where the contribution of $\omega$-hydroxy carboxylic acids decreased from OF $\left(3,910 \mu \mathrm{g} \mathrm{g}^{-1} \mathrm{OC}\right)$ to Bw horizons $\left(2,130 \mu \mathrm{g} \mathrm{g}^{-1}\right.$ $\mathrm{OC})$, The $\omega \mathrm{C}_{18: 1}$ remained the dominant compound also in the deeper horizons and $\omega \mathrm{C}_{24}$ and $\omega \mathrm{C}_{26}$ were not identified in the deepest analysed $\mathrm{Bw}$ horizon. In $\mathrm{CV}$, the total contribution of long chain $\omega$-hydroxy acids, predominating in suberins, increased along the profile from AE to BE. This trend was reported also by Otto and Simpson (2006) for a grassland-forest transition soil. The opposite trend was observed in CL site, where the contribution of $\omega$-hydroxy carboxylic acids decreased from OF to $\mathrm{Bw}$, as also found in recent studies (Naafs et al. 2005; Nierop et al. 2003) for a Umbric Andisol.

\section{$\alpha, \omega$-alkanedioic acids}

The $\alpha, \omega$-alkanedioic acids were a minor component in most plant and soil samples. While $\mathrm{C}_{16}$ and $\mathrm{C}_{18: 1}$ were identified in all plant tissues, $\mathrm{C}_{18}$ diacids were not released from leaves, while $\mathrm{C}_{20}$ and $\mathrm{C}_{22}$ diacids were observed only in root tissues. $\mathrm{C}_{12}-\mathrm{C}_{30}$ diacids are characteristic constituents of suberin (Kolattukudy and Espelie 1989; Bernards 2002). In CV soil both concentration and relative abundance of $\alpha, \omega$-alkanedioic acids increased from $\mathrm{AE}\left(1,444 \mu \mathrm{g} \mathrm{g}^{-1} \mathrm{OC}\right)$ to $\mathrm{E}\left(2,719 \mu \mathrm{g} \mathrm{g}^{-1} \mathrm{OC}\right)$ and again decreased in $\mathrm{BE}$ horizons $\left(1,751 \mu \mathrm{g} \mathrm{g}^{-1} \mathrm{OC}\right) . \mathrm{C}_{22}$ diacid was only identified in $\mathrm{AE}$ horizon. In $\mathrm{CL}$ the dominant diacid was $\mathrm{C}_{18: 1}$ in all horizons, except for $\mathrm{Bw}$, where $\mathrm{C}_{16}$ diacid was the only monomer identified within the $\alpha, \omega$-alkanedioic acid class. In the $\mathrm{OF}$ horizon only $\mathrm{C}_{16}$ and $\mathrm{C}_{18: 1}$ diacids were observed; Ah was the horizon with the highest concentration of alkanedioic acids and all compounds from $\mathrm{C}_{16}$ to $\mathrm{C}_{22}$ were found.

\section{Mid-chain-substituted hydroxy acids}

Mid-chain-substituted hydroxy and epoxy acids (Table 3) were also observed and represented the most prominent class in leaves $(84.2 \%$ in $\mathrm{CV}$ and $83.2 \%$ in CL) and woods (32.6\% in CV and $30.4 \%$ in CL). $x, 16$-dihydroxy hexadecanoic acids ( $x=8,9$ and 10) were the dominant compounds, followed by 9,10,18-trihydroxy octadecanoic acids and the epoxy acids. These compounds are the most common monomers identified in cutins (Kolattukudy and Espelie 1989; Bernards 2002; Kögel-Knabner 2002). The 9,10,18-triOHC ${ }_{18}$ may be in part original monomer or be formed from the conversion with the hydrolysis of a part of the 9,10-epoxy -18-hydroxy $\mathrm{C}_{18}$ (Goñi and Hedges 1990). The epoxy acids can only be identified indirectly by their hydrolysis products, as the epoxy group is readily hydrolyzed during the applied base hydrolysis and the epoxy acids are converted into geminal dihydroxy acids or methoxy derivatives (Holloway and Deas 1973; Holloway and Brown 1981). Compounds with the $m / z 530$ and 515 in their mass spectra were also identified in plant tissues except in the woody parts of the litter. They were previously attributed to the 11,18-dihydroxy octadecenoic acid $\left(11,18\right.$-diOH- $\left.\mathrm{C}_{18: 1}\right)$ and the mixture of 9,18- and 10,18-dihydroxy octadecenoic acids $(x, 18$ diOH-C $18: 1$, Mendez-Millan et al. 2011).

$x, 16$-diOH (Table 4 ) was the prominent compound in both studied soils, but with different trends along the profile: in $\mathrm{CV}$ the concentration remained almost constant, from 5,441 $\mu \mathrm{g} \mathrm{g}^{-1}$ in AE to 4,671 in BE, but relative abundance decreased from $25.9 \%$ in $\mathrm{AE}$ to $14 \%$ in $\mathrm{E}$ and $16.6 \%$ in $\mathrm{BE}$, while in $\mathrm{CL}$ both concentration and relative abundance decreased, from $8,918 \mu \mathrm{g} \mathrm{g}^{-1}$ OC (31.8\%) in OF to $894 \mu \mathrm{g} \mathrm{g}^{-1}$ OC $(8.5 \%)$ in $\mathrm{Bw}$. Considering the deepest horizon for both sites, only $x, 16$-diOHC $16,9,10,18$-triOHC ${ }_{18}$ and $9,10 \mathrm{EpC}_{18}$ were identified in the $\mathrm{Bw}(\mathrm{CL})$, while in $\mathrm{BE}$ horizon $(\mathrm{CV})$ a larger number of compounds were observed, including 9-OHC ${ }_{16} \mathrm{DA}, x-\mathrm{OHC}_{17}$ and 11,18-diOHC $18: 1$. 


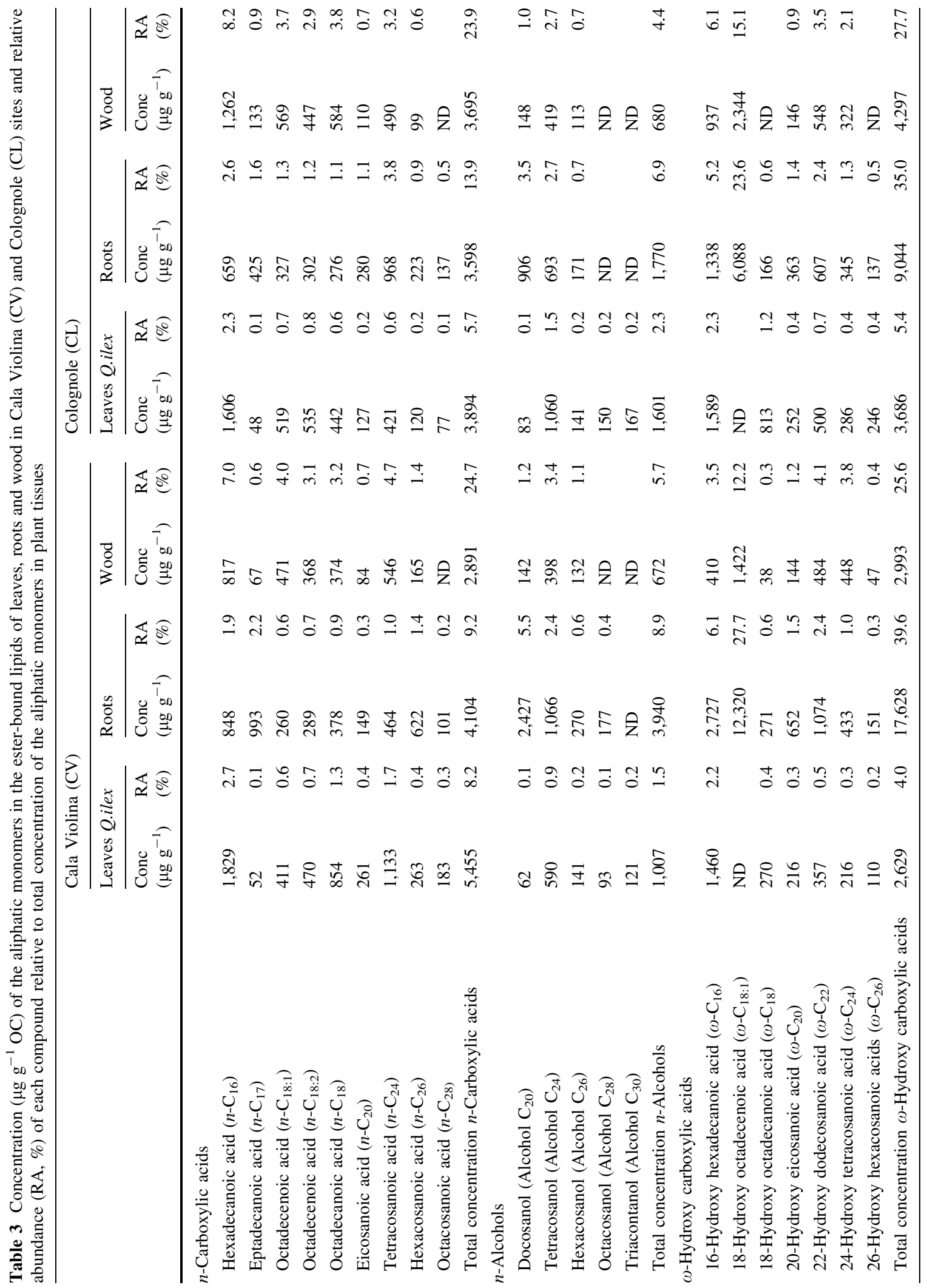




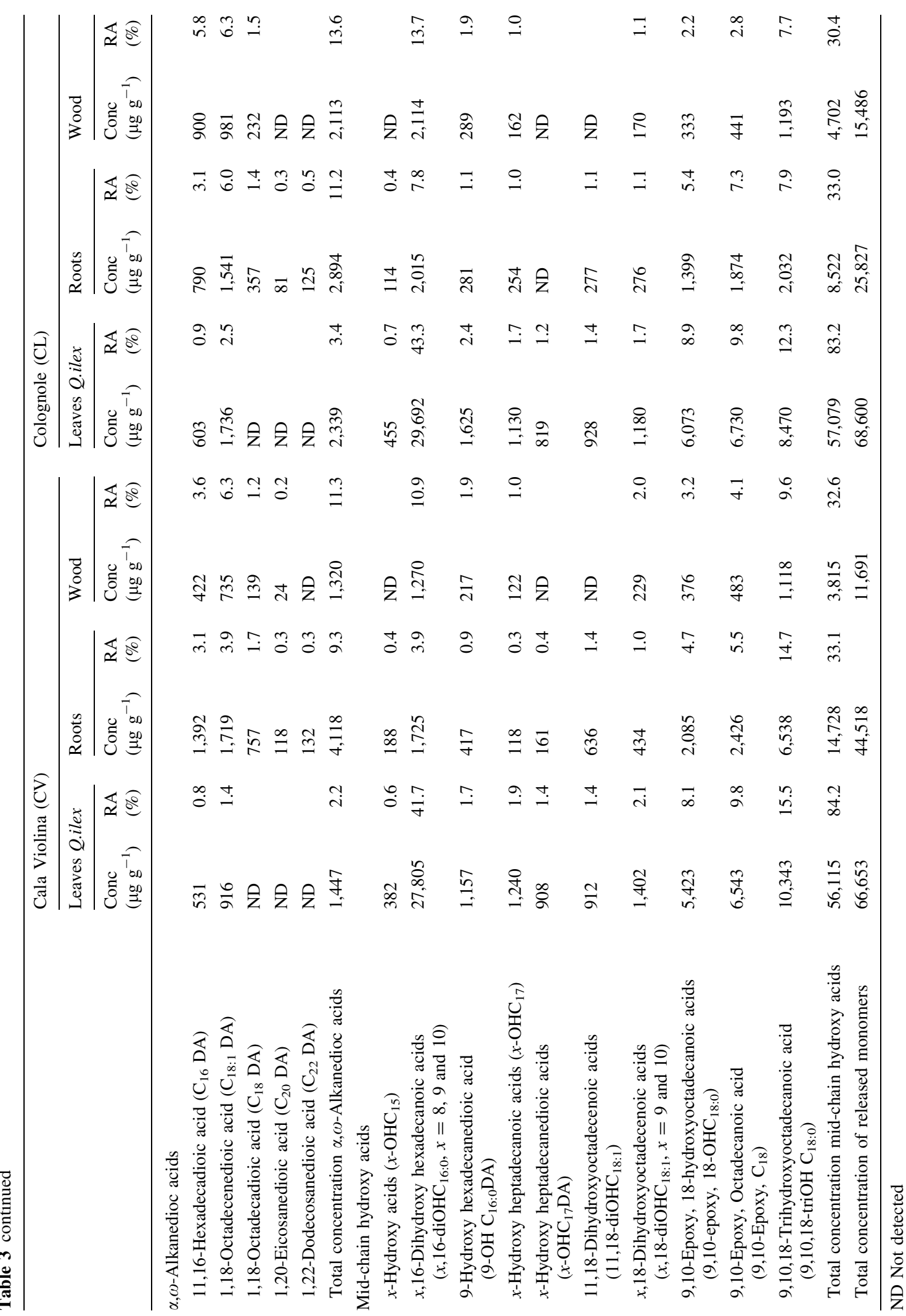




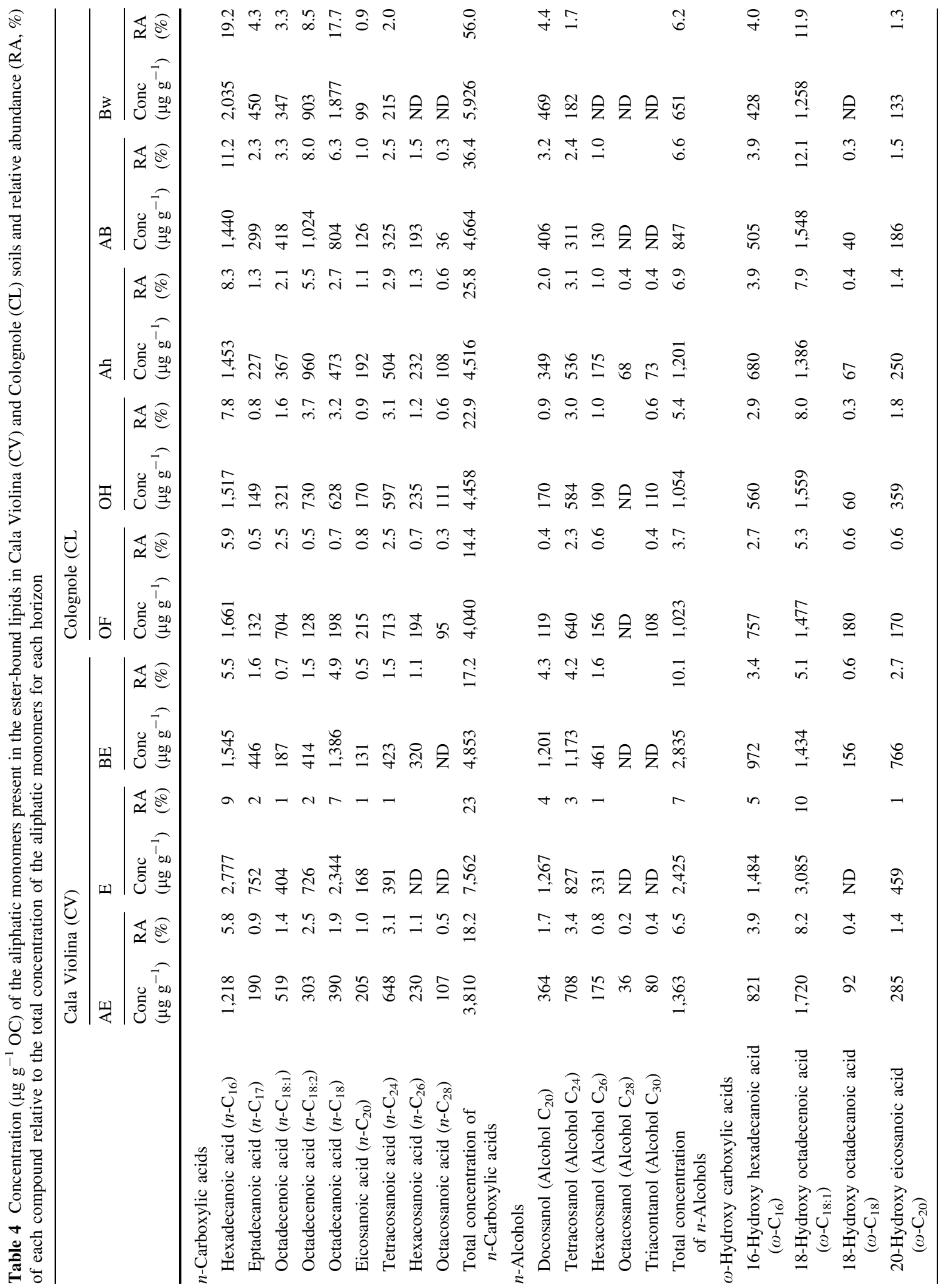




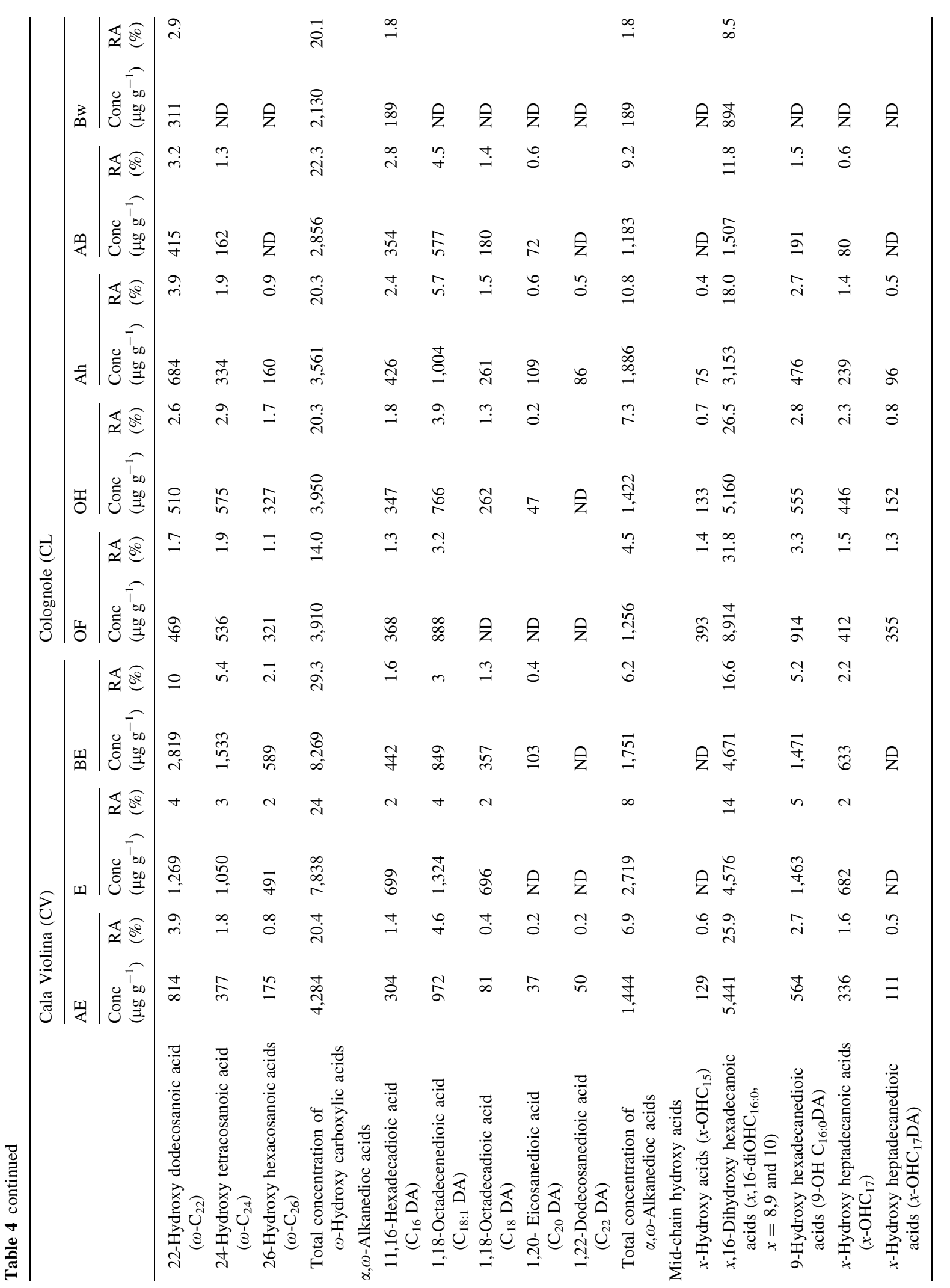




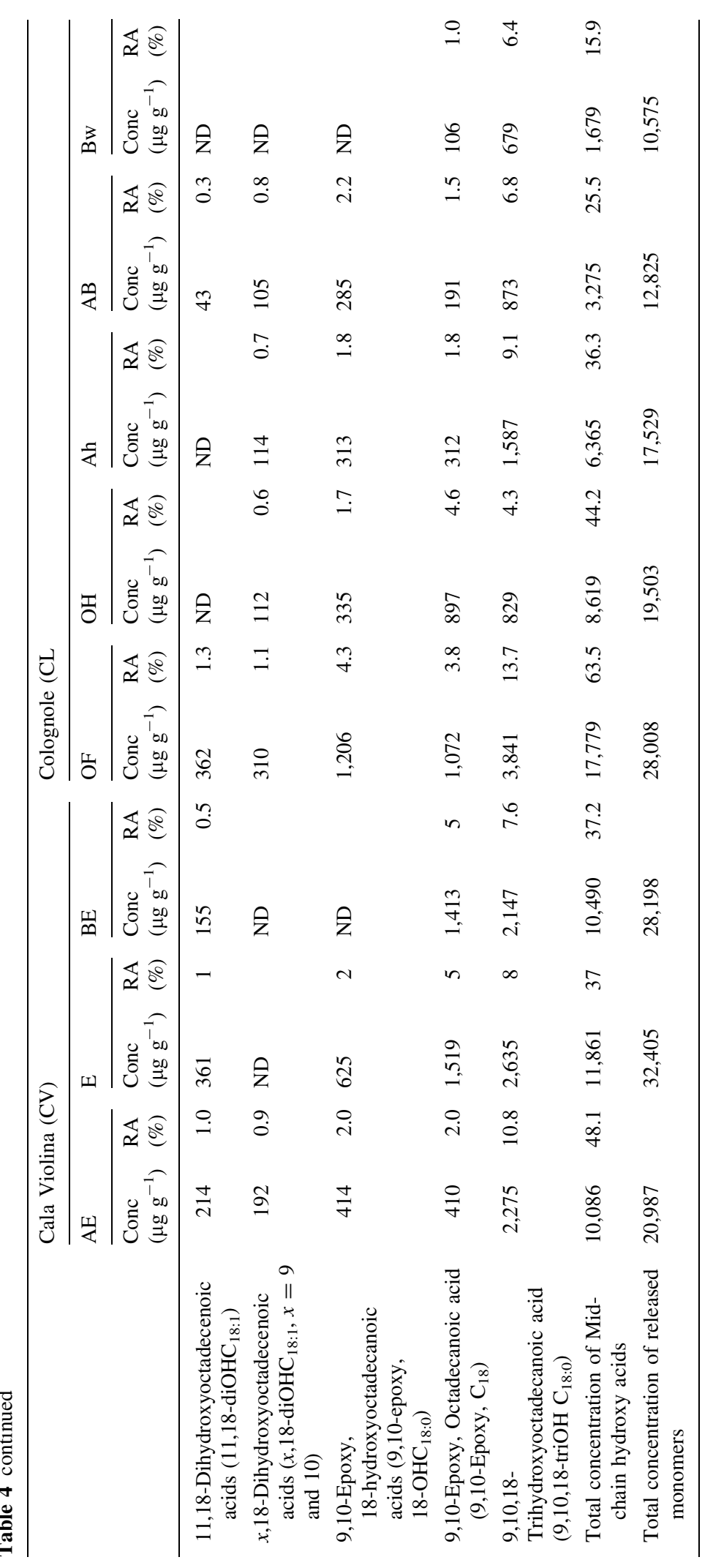


Identification of biomarkers

for below and aboveground plant tissues

In some studies, long-chain $\omega$-hydroxy acids were used to identify root $\mathrm{C}$ contribution to soil (Nierop et al. 2003; Otto and Simpson 2006). In this study, long chain $\omega$-hydroxy acids (Figs. 1,2) with more than 20 $\mathrm{C}$ were observed in all tissues, except for $\omega \mathrm{C}_{26}$ that was not released from woody parts. $\omega \mathrm{C}_{18: 1}$ was present with a high concentration in roots. Since long chain $\omega$-hydroxy acids were attributed to suberins
(Kolattukudy 1980; Bernards 2002), their high contribution in leaves suggests that these aboveground tissues contain suberized parts. The occurrence of suberized tissues in leaves might be related to adaptation of the studied plants to severe drought periods, typical for Mediterranean climate (Sardans and Peñuelas 2010). The $\omega$-hydroxy acids were considered specific for neither aboveground nor belowground plant tissues, except for $\omega \mathrm{C}_{18: 1}$ acid, that might be considered as a root marker in soil. In this study, alkanedioic acids, especially $\mathrm{C}_{20}$ DA and
Fig. 1 Aliphatic monomers of different plant tissues belonging to $\omega$-Hydroxy carboxylic, $\alpha, \omega$-Alkanedioic and Mid-chain hydroxy acids in Cala Violina (CV) site
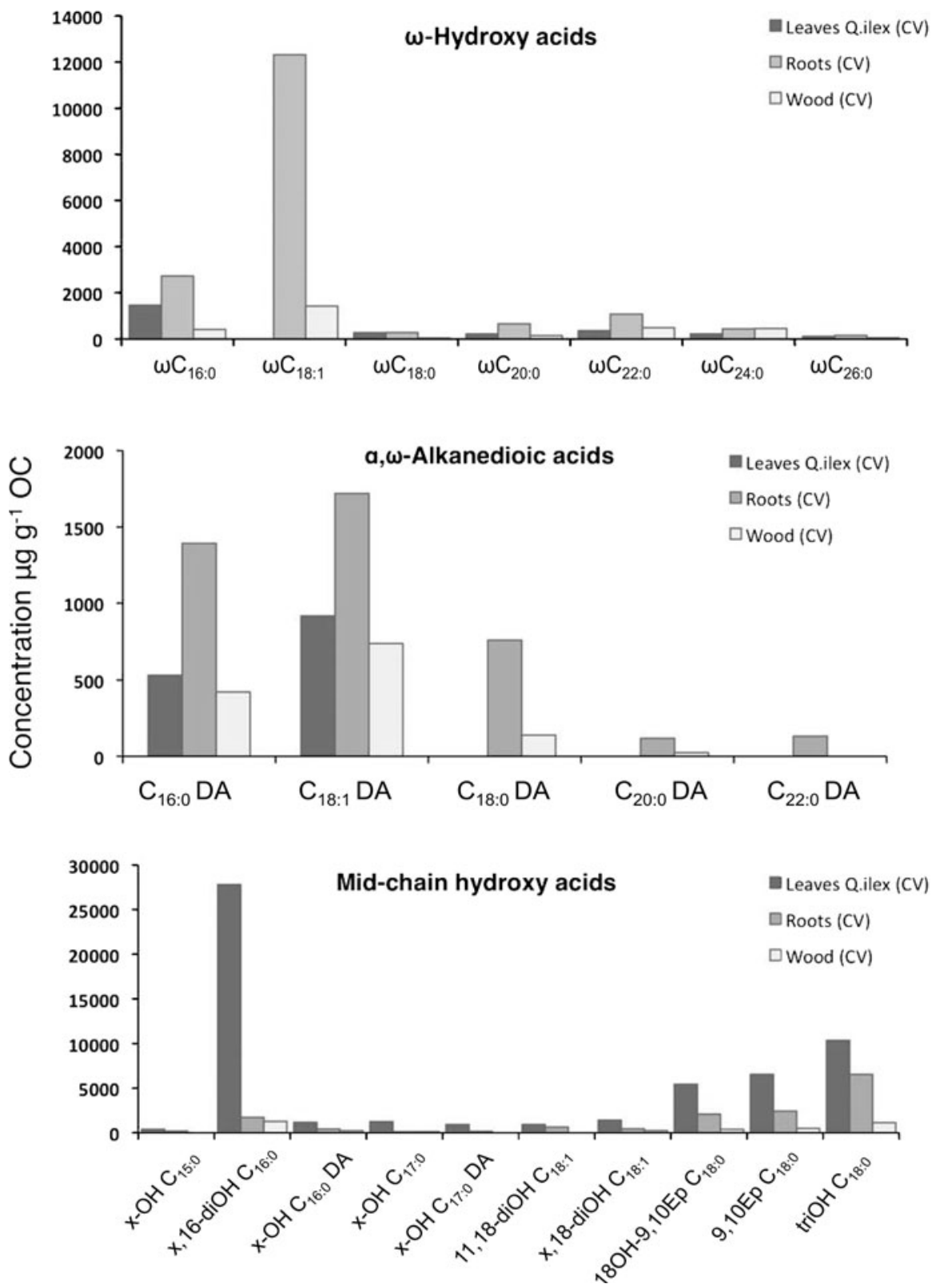
Fig. 2 Aliphatic monomers of different plant tissues belonging to $\omega$-Hydroxy carboxylic, $\alpha, \omega$-Alkanedioic and Mid-chain hydroxy acids in Colognole (CL) site
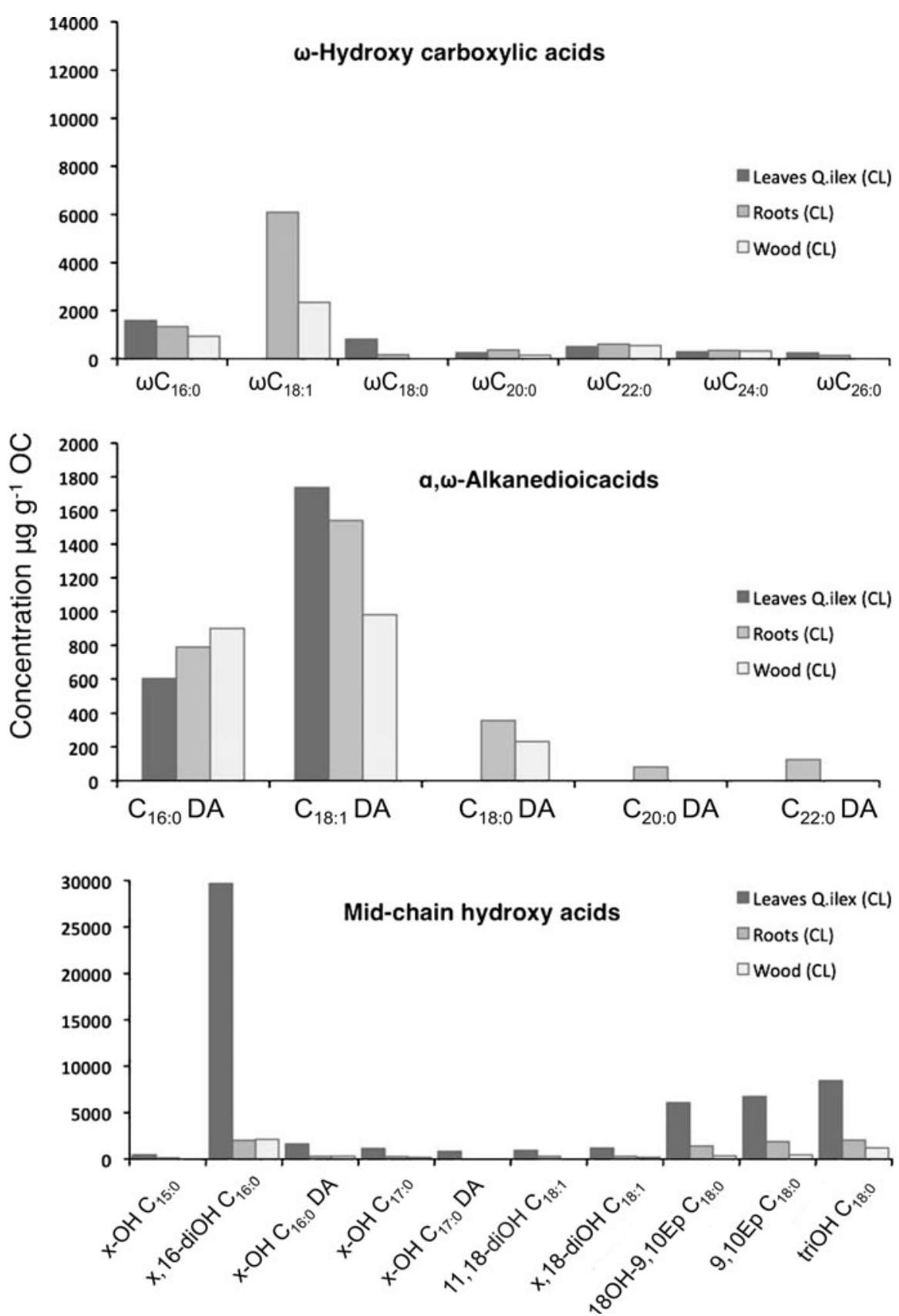

$\mathrm{C}_{22}$ DA, could be used as specific biomarkers for root tissues, since, as reported in literature (Mendez-Millan et al. 2010a, 2011; Otto and Simpson 2006), they are not released from leaves and woody parts of litter. $\mathrm{C}_{18}$ DA was also observed in woods, but in low concentration, especially in CV. This compound can be used as root marker in soil. Mid-chain hydroxylated carboxylic acids, except for 9,10,18-triOHC 18 , 11,18-diOHC $18: 1$ and the epoxy forms, can be considered as valuable biomarkers for leaves, as their concentrations were much higher in leaves than in other plant organs, as previously reported for cultivated plants (Mendez-Millan et al. 2011).

Leaf versus root biomarkers ratio

Aliphatic monomers, used as leaf biomarkers, showed completely different depth trends between the two 
soils. In $\mathrm{CV}$, their concentration remained constant along the profile, $6,644 \mu \mathrm{g} \mathrm{g}^{-1}$ in $\mathrm{AE}, 6,721 \mu \mathrm{g} \mathrm{g}^{-1}$ in $\mathrm{E}$ and $6,775 \mu \mathrm{g} \mathrm{g}^{-1}$ in $\mathrm{BE}$ (Fig. 3). In CL, the concentration of leaf markers decreased sharply, corroborating their aboveground origin, from the organic horizons OF $\left(10,905 \mu \mathrm{g} \mathrm{g}^{-1}\right)$ to the mineral soil Ah $\left(4,473 \mu \mathrm{g} \mathrm{g}^{-1}\right)$, and decreased further to reach $894 \mu \mathrm{g} \mathrm{g}^{-1}$ in $\mathrm{Bw}$, where only $x, 16-\mathrm{diOHC}_{16: 0}$ was identified (Fig. 4). In both sites the predominant rootspecific compound was $\omega-\mathrm{C}_{18: 1}$. In $\mathrm{CL}$, the highest amount of root biomarkers was found in the $\mathrm{Ah}$ horizon, where we observed that roots were mostly concentrated (Fig. 6). In CV, concentrations increased from $\mathrm{AE}\left(1,888 \mu \mathrm{g} \mathrm{g}^{-1}\right)$ to $\mathrm{E}\left(3,781 \mu \mathrm{g} \mathrm{g}^{-1}\right)$, and decreased again to $1,894 \mu \mathrm{g} \mathrm{g}^{-1}$ in $\mathrm{BE}$ (Fig. 5). Substantial differences between the two sites mainly concerned monomers specific for aboveground tissues

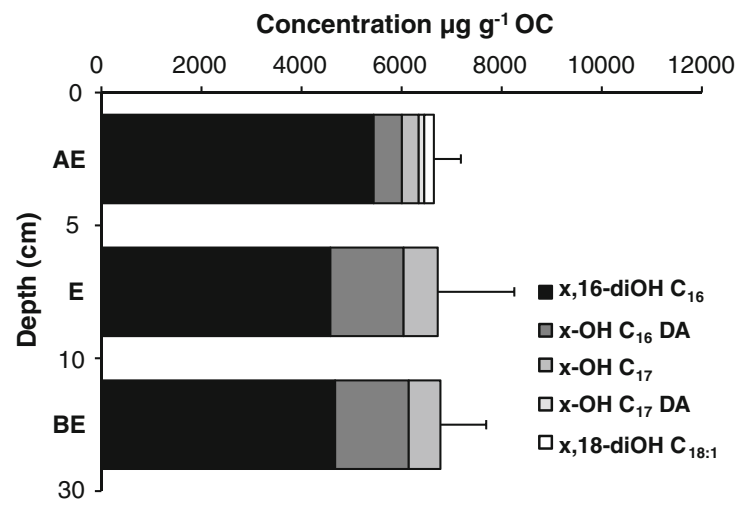

Fig. 3 Concentration and distribution of leaf biomarkers in Cala Violina $(\mathrm{CV})$ soil

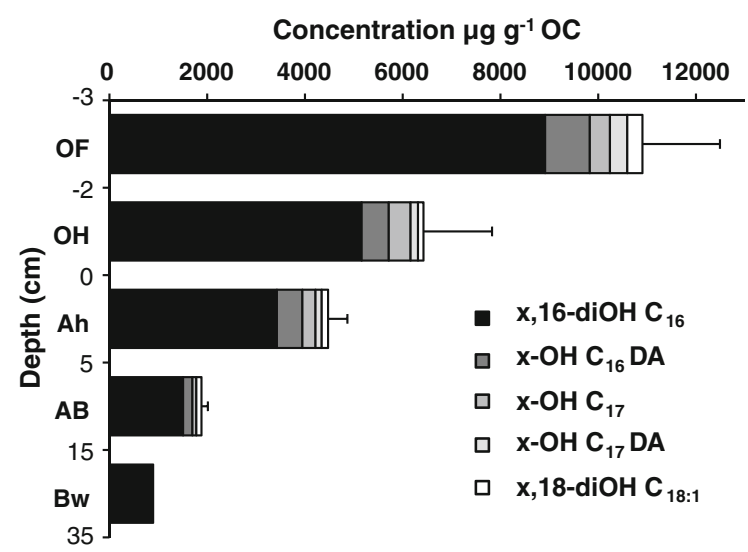

Fig. 4 Concentration and distribution of leaf biomarkers in Colognole (CL) soil

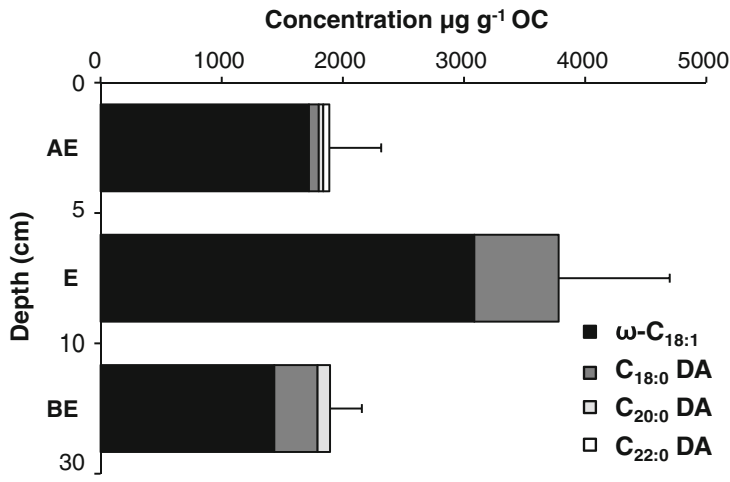

Fig. 5 Concentration and distribution of root biomarkers in Cala Violina $(\mathrm{CV})$ soil

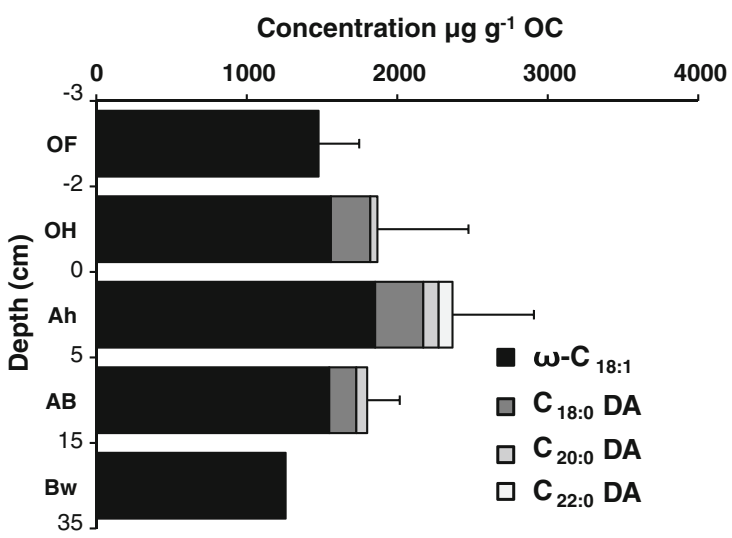

Fig. 6 Concentration and distribution of root biomarkers in Colognole (CL) soil

rather than those specific for belowground organs. In $\mathrm{CL}$ the dominant diacid was $\mathrm{C}_{18: 1}$ in all horizons, except for $\mathrm{Bw}$, where $\mathrm{C}_{16}$ diacid was the only monomer identified within the $\alpha, \omega$-alkanedioic acid class. As previously reported by Otto and Simpson (2006) for the LFH layer in a Canadian Brunisol, in the OF horizon only $\mathrm{C}_{16}$ and $\mathrm{C}_{18: 1}$ diacids were observed, which might be due to absence of roots in the fragmented litter layers. Aliphatic monomers specific for cutin and suberin, and their ratios, were used to discern the relative input of organic matter originating from roots and leaves to the soil (Otto and Simpson 2006; Naafs et al. 2005), as the assumption that cutin and suberin are characteristic biomacromolecules, respectively, of leaves and roots is well accepted. In this study, compounds that are often used as root biomarkers, as long chain $\omega$-hydroxy acids, were also found in leaves and woods. By contrast, monomers, 
Table 5 Root/leaf biomarkers ratio $(\Sigma \mathrm{r} / \Sigma \mathrm{l})$ for soils in Cala Violina e Colognole

\begin{tabular}{|c|c|}
\hline & $\Sigma \mathrm{r} / \Sigma \mathrm{l}$ \\
\hline \multicolumn{2}{|c|}{ Cala Violina (CV) } \\
\hline $\mathrm{AE}$ & 0.3 \\
\hline $\mathrm{E}$ & 0.6 \\
\hline $\mathrm{BE}$ & 0.3 \\
\hline \multicolumn{2}{|c|}{ Colognole (CL) } \\
\hline OF & 0.1 \\
\hline $\mathrm{OH}$ & 0.3 \\
\hline $\mathrm{Ah}$ & 0.5 \\
\hline $\mathrm{AB}$ & 1.0 \\
\hline $\mathrm{Bw}$ & 1.4 \\
\hline
\end{tabular}

such as $\omega \mathrm{C}_{18: 1}$ that was prominent in our root samples, were not included in the indexes developed in the literature.

Based on their occurrence in leaves and roots of the plants collected on our study sites, respectively, the following root and leaf biomarker ratio was developed (Table 5): root markers $(\Sigma \mathrm{r})$ include $\omega \mathrm{C}_{18: 1}$ and among the alkanedioic acids $\mathrm{C}_{18}, \mathrm{C}_{20}$ and $\mathrm{C}_{22}$; leaves markers $(\Sigma \mathrm{l})$ include mid chain substituted $\mathrm{C}_{17}$ hydroxy acids, mono hydroxy $\mathrm{C}_{16}$ and $\mathrm{C}_{17}$ diacids, dihydroxy $\mathrm{C}_{16}$ and $\mathrm{C}_{18: 1}$ acids. In $\mathrm{CL}$ an increase of the root/leaf ratio in the order $\mathrm{OF}<\mathrm{OH}<\mathrm{Ah}<\mathrm{AB}<\mathrm{Bw}$ was observed. The higher amounts of root-specific monomers in the mineral soil, as compared with organic horizons, were probably due to a higher input from roots. Furthermore, the proposed ratio also highlighted marked differences between the two soils. The root/leaf ratio calculated for CL soil horizons increased with depth from 0.1 in $\mathrm{OF}$ to 1.4 in $\mathrm{Bw}$ indicating the higher content in root markers in the deepest horizon, while the $\mathrm{CV}$ soil exhibited ratios $<1$ in all horizons, indicating a predominance of leaf markers.

\section{Discussion}

The soil depolymerisates differed between the studied sites and many differences were found in monomer occurrence and distribution with depth (Table 4). The organic compounds present in the source vegetation undergo various degradation and stabilization processes in the soil horizons. The relative decrease with depth in the ester-linked fraction of $\omega \mathrm{C}_{24}, \omega \mathrm{C}_{26}$ and dioic acids, observed in the $\mathrm{CL}$ mineral horizons, suggested that, upon decomposition in soil, they are more easily released from the polyester structure (Lopes et al. 2000; Nierop et al. 2003). This is due to their being placed at terminal positions of the polymer, as compared to other ester-linked aliphatic building blocks, which form the core of macromolecules. They then possibly form a more accessible part of the biopolyesters. Selective decomposition of some monomers (Nierop 1998) might have taken place. While this assumption could explain changes along the profile for these monomers in CL, a completely different trend was observed in $\mathrm{CV}$. The concentration of both $\omega \mathrm{C}_{24}$ and $\omega \mathrm{C}_{26}$ compounds increased from $\mathrm{AE}$ to $\mathrm{BE}$, while the total concentration of $\alpha, \omega$-Alkanedioc acids increased from $\mathrm{AE}$ to $\mathrm{E}$ and then decrease in $\mathrm{BE}$. This suggested that factors other than molecular structure affect the occurrence and distributions of aliphatic monomers in the soil.

Furthermore, monomers that were identified as leaf biomarkers rapidly decreased down the profile in CL, with a low concentration in $\mathrm{Bw}$. This degradation of the aliphatic monomers originating from leaves is consistent with the findings that cutins are not selectively preserved in soils (Kögel-Knaber et al. 1992; Riederer et al. 1993). In contrast, the concentration of leaf biomarkers remained constant along the profile in CV. A considerable mid-chain hydroxy acids accumulation in Cala Violina subsoil might partly be due to physical transport processes through the horizons with high content of sand (more than $80 \%$, Table 1) and the consequent downward movement of the organic matter within the soil. Rumpel and KögelKnabner (2011) suggested that downward transport of $\mathrm{OM}$ as dissolved organic matter (DOM) or bioturbation are major sources of $\mathrm{OM}$ in deep soil, along with the direct input from roots, which cannot be invoked for the accumulation of shoot biomarkers. However, Nierop and Buurman (1999) found a low contribution of aliphatic compounds to water soluble organic matter, in a Cambic Arenosols with signs of podzolization, suggesting that leaching of DOM might not be the main reason of leaf biomarkers accumulation. Bioturbation might explain the vertical transport of these compounds; though biological activity in $\mathrm{CV}$ topsoil is low, it has been suggested that humus form 
observed in $\mathrm{CV}$ is associated to summer drought forcing normally epigeic fauna, as enchytraeids and arthropods, down the mineral soil (Brêthes et al. 1995; Sadaka and Ponge 2003; Andreetta et al. 2011). On the other hand, CL humus form, is characterised by the common occurrence of arthropods, mainly localised in the $\mathrm{OF}$ and $\mathrm{OH}$ horizons, and earthworms in the mineral horizons (Galvan et al. 2008; Jabiol et al. 2007). The borrowing effect of anecic earthworms distributed the litter-derived carbon from the surface to deeper soil layers, but in the same time increases sequestration of litter-derived carbon in the soil system, mainly in microbial biomass (Ruf et al. 2006). Moreover their effect on SOM seems to depend on the time scale such that earthworms accelerate $\mathrm{C}$ degradation and mineralization initially, explaining the lower concentration of leaf markers per $\mathrm{C}$ unit in CL than CV, but slow SOM decay in the long term (Martin 1991; Brown et al. 2000; Lavelle et al. 2004), leading to higher OC content in the mineral horizons in CL than in CV (Tables 1, 2). Thus suggests that different faunal activities lead to different SOM degradation, differentiation and composition. Further work should be concerned with interpreting the mechanisms of leaf markers preferential preservation in Cala Violina and similar soils, investigating the concentrations of aliphatic compounds in DOC and the influence of biological activities, both of microorganisms and pedofauna, on cutin and suberin monomers degradations.

Degradation and preservation of organic compounds also depend from microbial activity. Microflora easily metabolizes fatty acids via $\beta$-oxidation, resulting in formation of shorter $n$-carboxylic acids (Dinel et al. 1990); such activity is however depressed by acidic soil conditions. Decreasing $\mathrm{pH}$ also changes the composition of the decomposer community (Nierop et al. 2003; Stevenson 1994). Very low soil pH (4.8 in $\mathrm{E}$ and 4.4 in BE, Table 1), may then be responsible for the accumulation of non-extractable ester bound moieties in CV soil through selective preservation and physico-chemical stabilization. Nierop et al. (2003) found an increase in base hydrolysable compounds with decreasing soil $\mathrm{pH}$. Acidity may be synergic with drought, and Bull et al. (2000) observed accumulation of lipids in acidic and dry soils due to inhibition of microbial activity.

Furthermore Bussotti et al. 2003 reported that the plants phonological behaviour differed in the two sites. Although litter production was lower and the leaf percentage in the total litterfall was smaller at $\mathrm{CV}$ $\left(235 \mathrm{~g} \mathrm{~m}^{2}\right)$ than at CL $\left(307 \mathrm{~g} \mathrm{~m}^{2}\right)$, trees renewed their crown almost completely each spring at $\mathrm{CL}$, whereas the leaves had greater longevity at $\mathrm{CV}$ with a gradual litterfall during the year. This leads to a continuous supply of fresh litter material in CV that may influences the fate of leaf biomarkers in soil.

In contrast the differences observed between the distributions of root makers in the two soils were less marked than for leaf markers. While the trend of root/ leaf biomarkers ratio increases with depth in CL, it is not continuous in $\mathrm{CV}$, where it increases from $\mathrm{AE}$ to $\mathrm{E}$ and then decreases from $\mathrm{E}$ to BE horizon. Especially vertical fine roots distribution could affect different composition and concentration of compounds specific for roots. In CL with higher mean annual precipitation $(925 \mathrm{~mm})$ and phonological behaviour similar to those reported for different temperate forest ecosystems (Bussotti et al. 2003), fine and very fine roots are most abundant in the uppermost mineral soil horizon (Ah) and decrease in frequency continuously with depth, as in most forest ecosystems (Hendrick and Pregitzer 1996; Steele et al. 1997). This may explain the highest concentration of root biomarkers in $\mathrm{Ah}$. In $\mathrm{AB}$ and $\mathrm{Bw}$ medium and coarse roots are more abundant and the concentration and composition of root biomarkers is lower than in Ah, thus suggesting that fine and very fine roots play a key role for the input of SOM. On the other hand, in the xeric site $(\mathrm{CV})$, fine roots are rare in the uppermost mineral soil (AE) and increase in frequency in the E horizon. López et al. 2001, considering a Quercus ilex stand with a mean annual precipitation $(537 \mathrm{~mm})$ close to those of $\mathrm{CV}$, found that fine root density parameters peaked in the 10-20 cm soil interval. This may explain the highest concentration of compounds specific for roots in the $\mathrm{E}$ horizon in $\mathrm{CV}$. The coarse texture of the soil, which may allow percolating water to carry nutrients, and the aridity of the site, which may cause the desiccation of the uppermost soil, seem to be the most likely factors that explain the relatively low frequency of fine roots in the $\mathrm{AE}$ horizon, and consequently of root biomarkers.

The preferential preservation of root-derived with regards to leaf-derived markers in CL (Table 5), may be explained by the relatively high amount of clay (Table 2) that contribute to physical protection and stabilisation especially within macroaggregates (Six 
et al. 2002). Close contact of root tissues with minerals (Rasse et al. 2005), together with interaction and binding on the mineral phase (Farrar et al. 2003) may promote root-markers stabilization. In $\mathrm{CV}$ this mechanism is not a likely factor in preservation of these compounds, because of the high sand content of mineral horizons and the weak development of soil structure. Preservation of root-derived compounds is likely due to, as hypothesised for leaf markers, $\mathrm{pH}$ and other factors that, depressing microbial activity, likely influence the fate of root-markers in this soil.

These results suggest that the quantitative and qualitative distribution of aliphatic compounds is controlled by a synergic effect of physico-chemical soil properties and biological activity of plants, pedofauna and microorganisms. Especially in the xeric soil and dry environment (CV) the strategies that plants, through roots distribution and litterfall, and pedofauna, adopted to cope with water and nutrients scarcity, lead to a preferential preservation of these compounds. Therefore, we suggest that ester-bound fractions can be important in the global carbon cycle, especially when climate change is considered.

\section{Conclusions}

To better understand the dynamics of SOM, two soils, $\mathrm{CV}$ and CL, characterized by humus forms considered emblematic for Mediterranean environments, were investigated. The study of aliphatic monomers, specific for cutin and suberin, led to the identification, through the analysis and comparisons of different plant tissues (leaves, roots and woods), of biomarkers that could be considered specific for plant root or leaf carbon. Mid-chain hydroxy acids were identified as aboveground biomarkers whereas $\alpha, \omega$-alkanedioic acids and $\omega-\mathrm{C}_{18: 1}$ can be considered as root markers. The contribution of these compounds was then estimated in the two soils. The contrasting distribution and concentration of the plant specific-monomers evidenced different mechanisms that might be responsible for the fate of root and leaf-derived organic matter in the soil profiles. These mechanisms may be related to soil physico-chemical properties and to soil biological activity. However the specific mechanism is still unclear and further investigation are needed. This approach showed the differences of organic matter fate in soils having two different humus forms, suggesting that humus forms also potentially provide information on SOC dynamics. However, the fact that only two sites were considered does not allow confirming this hypothesis and further studies on more sites and humus forms will be necessary.

Acknowledgments This research was supported by exchange grant received from the European Science Foundation (ESF) for the activity entitled "Natural molecular structures as drivers and tracers of terrestrial C fluxes" (MOLTER) EG/2960. The authors wish to thank Gérard Bardoux, Nicolas Pechot and Valérie Pouteau for their technical support and Mercedes Mendez-Millan for her support in the depolymerization method and in data interpretation.

\section{References}

Almendros G, Dorado J, González-Vila FJ, Blanco MJ, Lankes $\mathrm{U}(2000){ }^{13} \mathrm{C}$ NMR assessment of decomposition patterns during composting of forest and shrub biomass. Soil Sci Biochem 32:793-804

Andreetta A, Ciampalini R, Moretti P, Vingiani S, Poggio G, Tescari F, Matteucci G, Carnicelli S (2011) Forest humus as a potential indicator of soil carbon storage in Mediterranean environments. Biol Fertil Soils 47:31-40

Augris N, Balesdent J, Mariotti A, Derenne S, Largeau C (1998) Structure and origin of insoluble and non-hydrolyzable, aliphatic organic matter in a forest soil. Org Geochem 28:119-124

Bernards MA (2002) Demystifying suberin. Can J Bot 80: 227-240

Bigi L, Rustici L (1984) Regime idrico dei suoli e tipi climatici in Toscana. Regione Toscana, Dipartimento di Agricoltura e Foreste, Firenze

Brêthes A, Brun JJ, Jabiol B, Ponge JF, Toutain F (1995) Classification of forest humus forms: a French proposal. Ann Sci For 52:535-546

Brown GG, Barois I, Lavelle P (2000) Regulation of soil organic matter dynamics and microbial activity in the drilosphere and the role of interactions with other edaphic functional domains. Eur J Soil Biol 36:177-198

Bull ID, Nott CJ, Van Bergen PF, Poulton PR, Evershed RP (2000) Organic geochemical studies of soils from the Rothamsted classical experiments-VI. The occurrence and source of organic acids in an experimental grassland soil. Soil Biol Biochem 32:1367-1376

Bussotti F, Borghini F, Celesti C, Leonzio C, Bruschi P (2000) Leaf morphology and macronutrients in broadleaved trees in Central Italy. Trees 14:361-368

Bussotti F, Borghini F, Celesti C, Leonzio C, Cozzi A, Bettini D, Ferretti M (2003) Leaf shedding, crown condition and element return in two mixed holm oak forests in Tuscany, central Italy. For Ecol Manag 176:273-285

Crow SE, Lajtha K, Filley TR, Swanwon CW, Bowden RD, Caldwell BA (2009) Sources of plant-derived carbon and stability of organic matter in soil: implications for global change. Glob Chang Biol 15:2003-2019 
Dignac MF, Rumpel C (2006) Relative distributions of phenol dimers and hydroxy acids in a cultivated soil and above ground maize tissue. Org Geochem 37:1634-1638

Dinel H, Schnitzer M, Mehuys GR (1990) Soil lipids: origin, nature, content, decomposition, and effect on soil properties. In: Bollag M, Stotzky G (eds) Soil biochemistry, vol 6. Marcel Dekker, New York, pp 398-429

Eglinton G, Hunneman DH, McCormick A (1968) Gas chromatographic-mass spectrometric studies of long chain hydroxy acids. Org Mass Spectrom 1:593-611

FAO (2006) World Reference Base for Soil Resource 2006: a framework for international classification, correlation and communication: World Soil Resource Reports, vol 103

Farrar J, Hawes M, Jones D, Lindow S (2003) How roots control the flux of carbon to the rhizosphere. Ecology 84:827-837

Feng XJ, Simpson MJ (2007) The distribution and degradation of biomarkers in Alberta grassland soil profiles. Org Geochem 38:1558-1570

Galvan P, Ponge JF, Chersich S, Zanella A (2008) Humus components and soil biogenic structures in Norway spruce ecosystems. Soil Sci Soc Am J 72:548-557

Goñi MA, Hedges JI (1990) Cutin-derived CuO reaction products from purified cuticles and tree leaves. Geochim Cosmochim Acta 54:3065-3072

Harwood JL, Russell NJ (1984) Lipids in plants and microbes. George Allen and Unwin, London

Hendrick RL, Pregitzer KS (1996) Temporal and depth-related patterns of fine root dynamics in northern hardwood forests. J Ecol 84:167-176

Holloway PJ, Brown GA (1981) Ultrahistochemical detection of epoxides in plant cuticular membranes. J Exp Bot 32: 1051-1066

Holloway PJ, Deas AHB (1973) Epoxyoctadecanoic acids in plant cutins and suberins. Phytochemistry 12:1721-1735

Hunneman DH, Eglinton G (1972) The constituent acids of gymnosperm cutins. Phytochemistry 11:1989-2001

Jabiol B, Brêthes A, Ponge JF, Toutain F, Brun JJ (2007) L'humus sous toutes ses formes. ENGREF seconde édition, Nancy, France

Jansen B, Nierop KGJ (2009) Methyl ketones in high altitude Ecuadorian Andosols confirm excellent conservation of plant-specific n-alkane patterns. Org Geochem 40:61-69

Jansen B, Nierop KGJ, Hageman JA, Cleef AM, Verstraten JM (2006) The straight-chain lipid biomarker composition of plant species responsible for the dominant biomass production along two altitudinal transects in the Ecuadorian Andes. Org Geochem 37:1514-1556

Kögel-Knaber I, Hatcher PG, Tegelaar EW, de Leeuw JW (1992) Aliphatic components of forest soil organic matter as determined by solid-state 13C NMR and analytical pyrolysis. Sci Total Environ 113:89-106

Kögel-Knabner I (2002) The macromolecular organic composition of plant and microbial residues as inputs to soil organic matter. Soil Biol Biochem 34:139-162

Kolattukudy PE (1980) Biopolyester membranes of plants: cutin and suberin. Science 208:990-1000

Kolattukudy PE, Espelie KE (1989) Chemistry, biochemistry, and function of suberin and associated waxes. In: Rowe JW (ed) Natural products of woody plants I. Springer, Berlin, pp 304-367
Lavelle P, Charpentier F, Villenave C, Rossi JP, Derouard L, Pashanasi B, Andre J, Ponge JF, Bernier N (2004) Effects of earthworms on soil organic matter and nutrient dynamics at a landscape scale over decades. In: Edwards CA (ed) Earthworm ecology. CRC Press, Boca Raton, pp 145-160

Lopes MH, Gil AM, Silvestre AJD, Pascoal Neto C (2000) Composition of suberin extracted upon gradual alkaline methanolysis of Quercus suber L. cork. J Agric Food Chem 48:383-391

López B, Sabaté S, Gracia CA (2001) Annual and seasonal changes in fine root biomass of a Quercus ilex L. forest. Plant Soil 230:125-134

Lorenz K, Lal R, Preston CM, Nierop KGJ (2007) Strengthening the soil organic carbon pool by increasing contributions from recalcitrant aliphatic bio(macro)molecules. Geoderma 142:1-10

Marschner B, Brodowski S, Dreves A, Gleixner G, Gude A, Grootes PM, Hamer U, Heim A, Jandl G, Rong J, Kaiser K, Kalbitz K, Kramer C, Leinweber P, Rethemeyer J, Schaeffer A, Schmidt MWI, Schwark L, Wiesenberg LB (2008) How relevant is recalcitrance for the stabilization of organic matter in soils? J Plant Nutr Soil Sci 171:91-110

Martin A (1991) Short- and long-term effects of the endogeic earthworm Millsonia anomala (Omodeo) (Megascolecidae, Oligochaeta) of tropical savannas. Biol Fertil Soils 11:234-238

Mendez-Millan M, Dignac MF, Rumpel C, Rasse DP, Derenne $S$ (2010a) Molecular dynamics of shoot vs. root biomarkers in agricultural soil estimated by natural abundance ${ }^{13} \mathrm{C}$ labeling. Soil Biol Biochem 41:169-177

Mendez-Millan M, Dignac MF, Rumpel C, Derenne S (2010b) Quantitative and qualitative analysis of cutin in maize and a maize-cropped soil: comparison of $\mathrm{CuO}$ oxidation, transmethylation and saponification methods. Org Geochem 41:187-191

Mendez-Millan M, Dignac MF, Rumpel C, Derenne S (2011) Can cutin and suberin biomarkers be used to trace shoot and root-derived organic matter? A molecular and isotopic approach. Biogeochemistry 106:23-38

Naafs DFW, Van Bergen PF (2002) Effect of pH adjustments after base hydrolysis: implications for understanding organic matter in soils. Geoderma 106:191-217

Naafs DFW, Nierop KGJ, van Bergen PF, de Leeuw JW (2005) Changes in the molecular composition of esterbound aliphatics with depth in an acid andic forest soil. Geoderma 127:130-136

Nierop KGJ (1998) Origin of aliphatic compounds in a forest soil. Org Geochem 29:1009-1016

Nierop KGJ, Buurman P (1999) Insoluble organic matter fractions in incipient podzol B horizon: preservation of aliphatic biopolymers from roots. Humic Subst Environ 1:29-37

Nierop KGJ, Naafs DFW, Verstraten JM (2003) Occurrence and distribution of ester-bound lipids in Dutch coastal dune soils along a pH gradient. Org Geochem 34:719-729

Otto A, Simpson MJ (2005) Degradation and preservation of vascular plant-derived biomarkers in grassland and forest soils from Western Canada. Biogeochemistry 74:377-409

Otto A, Simpson MJ (2006) Sources and composition of hydrolysable aliphatic lipids and phenols in soils from western Canada. Org Geochem 37:385-407 
Rasse PD, Rumpel C, Dignac MF (2005) Is soil carbon mostly root carbon? Mechanisms for a specific stabilisation. Plant Soil 269:341-356

Riederer M, Matzke K, Ziegler F, Kögel-Knabner I (1993) Occurrence, distribution, and fate of the lipid plant biopolymers cutin and suberin in temperate forest soils. Org Geochem 20:1063-1076

Ruf A, Kuzyakov Y, Lopatovskaya O (2006) Carbon fluxes in soil food webs of increasing complexity revealed by $14 \mathrm{C}$ labelling and 13C natural abundance. Soil Biol Biochem 38:2390-2400

Rumpel C, Kögel-Knabner I (2011) Deep soil organic matter-a key but poorly understood component of terrestrial C cycle. Plant Soil 338:143-158

Rumpel C, Eusterhues K, Kögel-Knabner I (2004) Location and chemical composition of stabilized organic carbon in topsoil and subsoil horizons of two acid forest soils. Soil Biol Biochem 36:177-190

Sadaka N, Ponge JF (2003) Climatic effects on soil trophic networks and the resulting humus profiles in holm oak (Quercus rotundifolia) forests in the High Atlas of Morocco as revealed by correspondence analysis. Eur J Soil Sci 54:767-777
Sardans J, Peñuelas J (2010) Soil enzyme activity in a Mediterranean forest after six years of drought. Soil Sci Soc Am J 74:838-851

Six J, Conant RT, Paul EA, Paustian K (2002) Stabilization mechanisms of soil organic matter: implications for C-saturation of soils. Plant Soil 241:155-176

Steele SJ, Gower ST, Vogel JG, Norman JM (1997) Root mass, net primary production and turnover in aspen, jack pine and black spruce forests in Saskatchewan and Manitoba, Canada. Tree Physiol 17:577-578

Stevenson FJ (1994) Humus chemistry. Genesis, composition, reactions, 2nd edn. Wiley, New York

Tagger S, Périssol C, Criquet S, Aubert G, Neville P, Le Petit J, Toutain F (2008) Characterization of an amphimull under mediterranean evergreen oak forest (Quercus ilex): micromorphological and biodynamic descriptions. Can J Forest Res 38:268-277

Wiesenberg GLB, Gocke M, Kuzyakov Y (2010) Optimization of C-14 liquid scintillation counting of plant and soil lipids to trace short term formation, translocation and degradation of lipids. J Radioanal Nucl Chem 284:99-108 